KMETTY ZOLTÁN ${ }^{1}-$ KOLTAI JÚLIA²

KAPCSOLATHÁLÓZATOK MÉRÉSE - ELMÉLETI ÉS GYAKORLATI DILEMMÁK, LEHETŐSÉGEK ${ }^{3}$

DOI: $10.18030 /$ socio.hu.2015.4.34

\title{
ABSZTRAKT
}

A kapcsolathálózati megközelítés kétségkívül nagy divatját éli a mai szociológiában. Erre reflektálva egymással párhuzamosan több olyan kutatási módszer is kialakult, ami a kapcsolathálózatok mérésére koncentrál. Ezek a módszerek azonban elsősorban nem egymás alternatívái, sokkal inkább speciális kutatási célok elérését lehetővé tevő koncepciók. Tanulmányunkban a négy leginkább elterjedt ego-network mérési technikát járjuk körbe - névgenerátor, pozíciógenerátor, erőforrás-generátor, méretgenerátor - arra koncentrálva, hogy miIyen kutatási célokra használhatók az egyes módszerek, illetve milyen indikátorok nyerhetők ki belőlük. Külön kitérünk arra is, hogy a hálózatkutatással összefüggő kulcsfogalmak - társadalmi tőke, gyenge és erős kötések, homofília és heterofilia, stb. - hogyan illeszkednek ezen mérési módszerekhez. Mivel a méretgenerátor módszer a legkevésbé elterjedt az európai mérési tradícióban, valamivel részletesebben mutatjuk be az ebben rejlő lehetőségeket.

Kulcsszavak: kapcsolathálózat, névgenerátor, pozíciógenerátor, erőforrás-generátor, méretgenerátor

\section{MEASURING SOCIAL NETWORKS - THEORETICAL AND PRACTICAL DILEMMAS AND POSSIBILITIES}

ABSTRACT

Network approach is undoubtedly fashionable in today's sociology. Reflecting on this trend, a number of research methods have evolved side by side that concentrate on the measurement of social networks. However, these methods are not primarily the alternatives of each other, they are more conceptions that make the attainment of special research goals possible. In our paper, we describe the four most widespread egonetwork measuring techniques - namely the name generator, the position generator, the resource generator and the size generator - concentrating on the different research goals they can be used for and the kinds of indicators that can be obtained from them. We also address to how keywords connected to network research - such as social capital, weak and strong ties, homophily and heterophily, etc. - fit into these measurement methods. As size generator is the least common method in the European measurement tradition, more details are shown about its possibilities.

Keywords: social network, name generator, position generator, resource generator, size generator

1 ELTE TáTK Társadalomkutatások Módszertana Tanszék

2 MTA Társadalomtudományi Kutatóközpont Szociológia Intézet

3 A tanulmány az Integrációs és dezintegrációs folyamatok a magyar társadalomban című OTKA kutatás (108836) keretében készült. 
KMETTY ZOLTÁN - KOLTAI JÚLIA

KAPCSOLATHÁLÓZATOK MÉRÉSE

Elméleti és gyakorlati dilemmák, lehetőségek

\section{BEVEZETÉS ${ }^{4}$}

Bár a társas kapcsolatok vizsgálata hosszú múltra tekint vissza a szociológiában, a szúkebb értelemben vett kapcsolathálózati beágyazottság társadalmi hatásaira az elmúlt bő 40 évben kezdtek el koncentrálni a társadalomkutatók. Ehhez a kiinduló állításunkhoz azonban egy gyors kiegészítést is kell fúznünk. Természetesen, ha a mikro-csoportok szintjén vizsgálódunk, még további 40 évet visszamehetünk az időben, a szociometriai előzmények már az 1930-as években megjelentek. A hálózatkutatások ősei azok a szociometriai témájú kutatások voltak, melyek legelső képviselője Jacob Moreno volt (Moreno 1934), aki 1934-ben pszichoterápiás céllal kezdte feltárni a terápiás csoportok érzelmi hálóját. A vonzások és taszítások hálóját irányított gráfba rendezte, melyet szociogramnak nevezett. A szociometria fejlődésében elévülhetetlen érdemei voltak Mérei Ferencnek (többek között Mérei 1988), aki a módszer gyakorlati alkalmazásának kifejlesztésén dolgozott, és munkatársaival több mint 400 intézmény szociometriai vizsgálatát végezte el.

A hálózatkutatás az 1940-es, 1950-es évektől kezdett elkülönülni a szociometriától. Az új irányzat segítségével a kutatók makro-társadalmi jelenségeket próbáltak meg értelmezni, és egyre komolyabb matematikai hátteret használtak a munkákhoz. Az igazi fellendülést azonban az 1960-as évek hozták, amikor bekerült a tudományos köztudatba a véletlen gráfok elméletének emberi kapcsolathálózatokra való alkalmazásának lehetősége. Az Erdős és Rényi-féle paradigma (Erdős-Rényi 1960) egy új világra nyitott ablakot, amelynek matematikai szépsége és következetessége jelentős hatást gyakorolt a gráfelmélet későbbi munkáira (Barabási 2002).

A szociometriai kutatások azonban elsősorban mikro-csoportok vizsgálatára összpontosultak, míg a gráfelmélet társadalomtudományi lecsapódása ebben az időben inkább csak elméleti szinten hozott újdonságokat, a kapcsolathálózatok társadalmi szerepéről még nem tudott sokat mondani. Ez a helyzet megváltozik az 1990es, de főleg a 2000 évektől, ahogy egyre inkább lehetőség nyílik nagy társadalmi hálók vizsgálatára, részben a számítástechnikai kapacitások növekedésének, részben az elérhető adatmennyiségnek és köszönhetően. Ez egyébként egybeesik a big data program felfutásával is (magyar példaként lásd Koltai-Ságvári 2014, Vedres 2012).

Bár a kapcsolathálózatok szerepével és hatásaival (szocializáció, homofília, média-befogadás, stb.) több könyvtárnyi szociológia mű foglalkozott, az 1970-es évek végéig hiányoztak azok a survey-módszerek, amelyek ego-hálók alapján komplex módon tudtak volna számot adni a kapcsolatok társadalmi szintű szerepéről. Az évtized végén megjelent névgenerátoros módszer azonban lehetőséget adott arra, hogy országos survey vizsgá- 
latok keretei között is komplex kapcsolathálózati mechanizmusokat vizsgáljanak a kutatók (McAllister-Fischer 1978).

Tanulmányunkban négy ego-háló mérésére alkalmas módszert - névgenerátor, pozíciógenerátor, erőforrás-generátor, méretgenerátor - mutatunk be részletesen. A módszerek, ahogy a későbbiekben részletesen is körbejárjuk, nem egymás helyettesítésére szolgálnak: mindegyiknek megvan a maga előnye, hátránya, és mindegyik módszer más kutatási kérdés megválaszolására alkalmas. A módszerek kiválasztása természetesen nem volt önkényes, ezek a leggyakrabban előforduló network mérési technikák a szociológiában. A következőkben tehát bemutatjuk a négy módszer elméleti alapjait, alkalmazásának módját, valamint a módszerből kinyerhető mutatókat, statisztikákat. Mivel a méretgenerátor a legkevésbé ismert hazai szinten (és Európában sem elterjedt), ezért az utóbbi módszerben rejlő lehetőségeket igyekszünk alaposabban körbejárni. A tanulmány keretei szúkre szabják a lehetőségeinket, ezért számos további érdekes módszertani és elméleti kérdésre és következményre csak utalni tudunk, részletesen kifejteni már nem. Ahogy a fentiekben jeleztük, ez a tanulmány kizárólag az ego-network vizsgálati módszerekkel foglalkozik, a teljes hálók vizsgálati lehetőségeit és módszereit nem érinti (Wasserman-Faust 1994). Az ego-network módszerekről sem adunk teljes képet: a következőkben bemutatott generátor technikák mellett vannak további mérési módszerek, mint az egyszerúbb, 1-2 itemes kérdések használata (pl: hány barátja van, Albert-Dávid 2007), vagy akár a naplós módszer (Fu 2008, magyar alkalmazása kapcsán lásd: Huszti 2013, 2015).

\section{NÉVGENERÁTOR}

Ahogy már a bevezető részben is hangsúlyoztuk, a személyközi kapcsolathálózat vizsgálata hosszú ideje fontos aspektusa a szociológiai elemzéseknek, azonban az 1978-ban Fischer és McAllister (1978) által publikált névgenerátoros módszer ${ }^{5}$ előtt nem volt olyan standard technika, amely komplex módon lehetőséget nyújtott volna a kapcsolathálózatok vizsgálatára. A módszer kidolgozásánál a szerzők arra törekedtek, hogy egy személynek azt a maghálózatát térképezzék fel, amely a leginkább befolyásolni tudja az attitűdjeit és lehetőségeit.

A névgenerátoros kérdőív első felében a válaszadóknak különböző szituációkban kell megmondaniuk, hogy kikre számíthatnak (például kitól szokott tanácsot kérni, kitől szokott pénzt kérni). Az eredeti kutatásban minden kérdésre maximum nyolc nevet mondhattak a résztvevők, és összesen tíz szituációra kellett válaszolniuk. A kérdések leginkább expresszív, illetve affektív hangsúlyúak voltak, egyes esetekben azonban előkerültek instrumentális motívumok is (pénzt kölcsönkérni). A kérdések megtervezésében kiemelten fontos szempont volt, hogy a kapcsolatok „csere-jellegét” hangsúlyozzák. Tehát például nem arra kérdeztek rá, hogy „ki áll a kérdezetthez legközelebb”, hanem arra, hogy „kire számíthatsz a mindennapi feladataid során”. Az előbbi kérdés ugyanis sokkal több egyéni interpretációs szabadságot ad a kérdezettnek, ami összességében a kérdés alacsonyabb szintű érvényességéhez vezet.

A kérdéssor végén összeirrták egy listára a neveket, és megkérdezték a válaszolót, hogy van-e még olyan fontos szereplő a környezetében, aki esetleg nincs a listán, és ha volt, akkor őt is felírták. A következő lépésben

5 Bár a technika alapjait nem ők dolgozták ki (lásd: Marsden 1990), már korábbi szerzőknél is megjelent, de a koncepció kiszélesítése és pontosítása az ő nevükhöz fúződik. 
a kapott lista tagjairól további kérdéseket tettek fel, például megkérdezték az alterek a nemét, iskolai végzettségét, vallását. A legvégén a kérdezettnek ki kellett választani az öt legfontosabb kapcsolatát, és róluk még egy önkitöltős kérdőívet is kitöltettek a válaszolókkal. A módszerrel információt lehet nyerni az ego kapcsolathálózatának sűrúségérőll (lásd később), illetve a kapcsolattartás intenzitásáról is. Ez egy viszonylag időigényes módja a kapcsolathálózat feltárásának, azonban roppant széles körú információt képes nyújtani arról. Az eredeti névgenerátoros módszert kutatástól függően többféle módon is implementálták, változtattak a névelőhívó kérdéseken és az alterek attribútumait vizsgáló kérdéseken is, de az alapmódszer minden vizsgálatban tetten érhető (Marsden 1990).

A módszer elsősorban a közeli-erős kötések mérésére alkalmas. Kritikaként fogalmazzák meg a technikával szemben, hogy a kérdőívében a blokkok hossza miatt az ilyen jellegú adatok megbízhatósága megkérdőjelezhető, illetve sem a megfelelő kérdések, sem az eredmények standardizálása kapcsán nincs konszenzus a kutatók között, ezért az eredmények nehezen összehasonlíthatók egymással (Lin-Erickson 2008). ${ }^{6}$ Lin (2008) megjegyzi, hogy a névgenerátoros módszer elsősorban a kapcsolathálózati erőforrásokhoz (az ő szóhasználatában társadalmi tókéhez) való hozzáférést tudja mérni.

Lin kritikája a módszer által igényelt kérdőív hossza kapcsán valóban jogos. A tanulmányban bemutatott mérési technikák közül ez igényli a leghosszabb kérdezési időt. A nem egységes definíciós keret és a névinterpretáló kérdések különbségei miatt kialakuló értelmezési problémák szintén fennállnak, bár azt meg kell jegyezni, hogy vannak törekvések olyan módszerek kidolgozására, melyekkel kevés névelőhívó kérdésre támaszkodva jobban tudják mérni a magkapcsolatokat (Marin-Hampton 2007).

Az elemzési lehetőségek két szinten mozognak, a relációs adatbázis és az ego adatbázis szintjén. A relációs adatbázis az összes felvett kapcsolatot tartalmazza, míg az ego adatbázis már a kérdezett szintjére (dez) aggregált kapcsolathálózati mutatókat. A legtöbb elemzési módszer az ego hálózatokra koncentrál, a relációs adatbázisra általában kevesebb figyelem vetül (bár vannak ellenpéldák: Snijders-Spreen-Zwaagstra 1995, Marsden 2003, Kowald-Axhausen 2011).

A kérdezett szintjén a legtriviálisabb mutató a kapcsolathálózat nagysága, tehát az összes olyan ember száma, aki szerepel a névelőhívó kérdések válaszaiban. A hálózat nagysága természetesen erősen konstrukciófüggő: egyrészről a kérdések száma, másrészről a kérdések átfedő jellege is befolyásolja (Kogovsek-Mrzel -Hlebec 2010). A kapcsolathálózat volumene gyakorlatilag a mag-kapcsolathálózati erőforrások nagyságának az indikátora. Fontos, hogy az így nyert mutató nem tekinthető társadalmi tőke indikátornak, mivel elsősorban olyan affektív jellegű előnyöket jelent a nagyobb kapcsolati háló, melynek „tőke” értelmezése megkérdőjelezhető (Angelusz 2010, Sik 2006, 2012, Kisfalusi 2013). A magkapcsolatok száma mellett a második érdekes kérdés a kapcsolatok uniplex-multiplex jellege. Uniplex kapcsolat alatt azt értjük, hogy egy alter szereplő csak egy szerepben van, multiplex esetben pedig legalább két szerepben (tehát például vele beszéli meg az ego a legfontosabb problémáit, és szórakozni is vele jár el). Ez vizsgálható mind az ego, mind a relációs adatbázis szintjén. Ennek kapcsán egyrészről elemezhetők a különböző szerepátfedések, másrészről különböző kapcsolathálózat-

6 Lin részéről a kritika persze érthető, hiszen a névgenerátor konkurenciájának tekinthető pozíció-generátor technika köthető a nevéhez. 
alakító stratégiák is megkülönböztethetőek. A multiplex jelleg erősebb affektív kötődésekre utal, azonban sebezhetőbbé is teszi az egot, mivel egy kapcsolat elvesztése több dimenzióban is nehéz helyzetbe hozhatja.

A kapcsolathálózati erőforrások diverzifikáltsága legalább annyira fontos, mint azok volumene. Minél heterogénebb valakinek a hálózata, annál valószínúbb, hogy hozzáfér számára hasznos erőforrásokhoz is (Flap 1991, Lin 2001). Tehát nem elég az, hogy valakinek nagyon széles a kapcsolatrendszere (mivel ezek a kapcsolatok gyakran ugyanahhoz az erőforráshoz kötődnek), hanem az is fontos, hogy minél sokrétúbb legyen.7 A kapcsolathálózatok fontos jellemzője, hogy az emberek általában magukhoz hasonló emberekkel veszik körül magukat. Ezt nevezik a szakirodalomban homofíliának (Lazarsfeld-Merton 1954, Lin 2008; McPherson et al. 2001). A homofília egyrészről strukturális hatások miatt jön létre (lakókörnyezet, iskola, munkahely), másrészről szociálpszichológiai mechanizmusok is alakítják (Lazarsfeld-Merton 1954). A kapcsolatok diverzifikáltságát általában a homofília-heterofília nagyságával szokták mérni. A kapcsolatok diverzifikáltsága két oldalról is megközelíthető. Egyrészről vizsgálható, hogy a kérdezetthez képest az alterek hálója bizonyos attribútumok mentén mennyire homogén. Tehát például, egy női ego esetében az alterek csak nők (homofil háló), vagy vannak benne férfiak is (heterofil háló). Természetesen a heterofília nagyságát is lehet operacionalizálni, de általában ilyen mélységekben már nem szokták vizsgálni a kapcsolathálózatokat. A másik lehetőség, hogy csak az alterekre koncentrálunk, és az alterek adott attribútum szerinti megoszlása alapján állapítjuk meg a heterofília nagyságát. Ehhez használatos statisztika például a „Simpson's Index of Qualitative Variation”, röviden IQV-mutató (Marsden 1987), ami diszkrét valószínűségi változók egyenletes eloszlástól való különbözőségét méri. A kapcsolathálózat nagysága és diverzifikáltsága között általában pozitív a korreláció, azaz minél nagyobb valakinek a kapcsolatrendszere, valószínúleg annál heterogénebb is. Ez részben módszertani okokkal is magyarázható, és a network-változók szerkezeti felépítéséből következik. ${ }^{8} \mathrm{Az}$ is általánosan jellemezi a kapcsolati hálókat, hogy ha valakinek az egyik szempontból (például iskolai végzettség) heterofil a kapcsolathálója, akkor vélhetően más változók (például nemi összetétel) mentén is heterofil lesz.

A kapcsolathálózat nagysága és volumene mellett általában kisebb hangsúlyt helyeznek a névgenerátoros módszerre építő elemzések a kapcsolathálózat struktúrájára, például arra, hogy mennyire telített/sűrű az ego és az alterek közötti teljes hálózati struktúra. A sürúbb hálózatok általában kevésbé heterogének, kisebb az esélye a strukturális lyukak (Burt 1992) előfordulásának, és ezért kapcsolathálózati erőforrások szempontjából kevésbé „hasznosak”. Utóbbi megállapítás főleg az üzleti világgal kapcsolatos erőforrások felhasználást érinti, más dimenziók esetében ez az összefüggés nem feltétlen igaz (Van der Gaag 2005). A legtöbb névgenerátoros kérdéssorban helyhiány miatt általában lemaradnak a mélyebb struktúrára vonatkozó kérdések, de például a korábban hivatkozott Fischer-McAllister-féle kutatásban rákérdeztek az ego összes előhívott kapcsolata esetében páronként, hogy ki-kinek az ismerőse (hasonló magyar példa kapcsán lásd Angelusz-Tardos 1988).

7 A heterogenitás azonban nem minden esetben jelent előnyt. A politikai kapcsolatok esetében a heterofil véleményháló (ha olyan személyek vannak a családi, baráti, ismerősi kapcsolati hálónkban, akik más pártokkal szimpatizálnak) alacsonyabb választási részvételhez vezethet, ami a demokrácia deficitnek egy szindrómája (Mutz 2002a, 2002b, Huckfeldt-Mendes 2008, KmettyKoltai 2012, Kmetty 2014)

8 Ha valakinek csak egyetlen kapcsolata lesz, akkor biztos például, hogy homofil a kapcsolathálója. 
A névgenerátor módszert több országos reprezentatív kutatás is használta Magyarországon. Angelusz Róbert és Tardos Róbert (1988) az 1987-88-as Kulturális-Interakciós vizsgálatsorozatában egy 8 itemes verzióját implementálta a magyar viszonyokra, míg 1997-ben egy rövidebb, 3 itemes verzió került lekérdezésre vezetésükkel (Angelusz-Tardos 1998). A DKMKA alapítvány választáskutatási programjának keretében (www. valasztaskutatas.hu) 2003-ban és 2008-ban is lekérdezésre került ugyanez a három itemes verziója a névgenerátornak (lásd még Angelusz-Tardos 2006, 2009).

\section{POZÍCIÓGENERÁTOR}

A pozíciógenerátor az alapsémában a társadalmi tőke hozzáférést azon keresztül méri, hogy milyen különböző munkakörökben dolgozó emberekkel van ismeretsége a kérdezettnek. A foglalkozási pozíciógenerátort először Lin és Dumin (1986) használta arra az elméleti sémára építve, hogy az instrumentális cselekvés, ami a gazdagság/hatalom/státusz-erőforrások megszerzésére irányul, végső soron jól operacionalizálható a foglalkozási hierarchiával. A megfogalmazás a másik irányból indítva még jobban érthető. A társadalmi erőforrásokhoz való hozzáférés és azok használata befolyásolja az instrumentális cselekvéseink sikerét.

Linék abból indultak ki, hogy a társadalmi struktúrában az emberek piramis-szerűen helyezkednek el, a vertikális elhelyezkedést pedig elsősorban a vagyon, a státusz és a hatalom befolyásolja (Lin-Dumin 1986: 367). Minél magasabban helyezkedik el valaki ebben a piramisban, annál több társadalmi erőforráshoz fér hozzá. Linék ezt kiegészítik azzal, hogy azoknak az instrumentális cselekvései lesznek nagyobb valószínűséggel sikeresek, akik olyan kapcsolatokkal rendelkeznek, amelyek magas pozícióban lévő alterekhez kötik őket a hierarchiában. Például munkakeresés esetén nagyobb eséllyel indul az, aki magas státuszú ismerősökkel rendelkezik, mint az, aki csak alacsony státuszúakkal. Linék azt is feltételezték Granoveterre (1973) hivatkozva, hogy a gyenge kötések hasznosabbak az instrumentális cselekvések szempontjából, mivel nagyobb valószínűséggel érnek el olyan erőforrásokat, amelyekhez az ego egyébként nem tudott hozzáférni. A pozíciógenerátoros módszer alapsémájában a társadalmi erőforrásokhoz való hozzáférést a különböző munkakörökön keresztül operacionalizálják. Tehát a fent említett piramisszerű elrendezésben az ego helyzetét Linék szerint jól méri a kérdezett foglalkozása, a társadalmi erőforrásokhoz való hozzáférést pedig az, hogy milyen foglalkozásokat ér el valaki a kapcsolathálójában. Fontos megkülönböztetés, hogy a pozíciógenerátor alapesetben az erőforrások elérését mutatja, nem a mobilizálhatóságát, bár utóbbi hasznosabb kapcsolati tőke szempontból. Fontos eltérés a névgenerátorhoz képest, hogy ez a módszer nem a kapcsolathálózat nagyságát méri, hanem azt, hogy a társadalmi struktúrában milyen pozíciókhoz fér hozzá a kérdezett, ilyen szempontból tehát sokkal inkább mezomegközelítésnek tekinthető.

Bár a fenti alapötlet nem tûnik bonyolultnak, a megvalósítás több kritikus kérdést is felvet. A legfontosabb ilyen kritikus kérdés, hogy hány foglalkozás elérését vizsgálja a módszer, és mik legyenek ezek a foglalkozások. Lin és Dumin (1986) húsz foglalkozást választottak ki, amelyek megfelelően reprezentálták a teljes foglalkozási rangsort egyrészt gyakoriság, elterjedtség szempontjából, másrészt presztízs alapján is lefedték a teljes spektrumot. 
Ebben a fejezetben párhuzamosan használjuk a társadalmi erőforrás és a társadalmi tőke kifejezéseket. Bár a szakirodalom nem egységes a pontos szóhasználatban (főleg a társadalmi tőke definíciós problémái miatt), a pozíciógenerátoros módszer kialakítója, Lin $(1999,2001)$ is hajlik arra, hogy a két fogalmat párhuzamosan használja. A névgenerátor esetében, mivel alapvetően affektív cselevési zónák vannak a fókuszban, félrevezető a társadalmi tőke kifejezés használata, azonban a pozíciógenerátor esetében, ami az instrumentális cselekvésekre épít, használhatóbb lehet a fogalom.

Az eddigi magyar vonatkozású tanulmányokban (összefoglalva lásd Angelusz-Tardos 2008) a pozíciógenerátorra építve általában olyan mutatót generáltak, ami a társadalmi tőke volumenét mérte azáltal, hogy hány foglalkozási csoporthoz van kapcsolata a kérdezettnek. Ezt nevezte Angelusz Róbert és Tardos Róbert nexusdiverzitásnak (Nan Lin hasonló fogalmára támaszkodva). Ha a foglalkozásokat összekötjük a foglalkozások presztízsrangsorával, a lehetséges indikátorok száma jelentősen megnő. Nemzetközi vonatkozásban ilyen lehetséges foglalkozási presztízspontszám az ISEI (Ganzeboom-Treiman: 1996), vagy a SIOPS pontszám (Treiman 1977). Bár a különböző mobilitási vizsgálatokban előszeretettel használják ezeket a nemzetközi indikátorokat, de a magyar foglalkozási hierarchiának feltehetően nem a legjobb proxyjai. ${ }^{9}$ A pontszám hozzárendelését nehezíti, hogy Magyarországon 1984-ben készült az utolsó presztízsvizsgálat (Kulcsár 1985). A jóval a rendszerváltozás előtt készített kutatás 30 évvel későbbi felhasználása nem jó választás, a nemzetközi rangsorok valószínúleg még mindig jobban felhasználhatók. A presztízsskála alapján négy további mutatót lehet kialakítani a pozíciógenerátor kérdésekből (Lin-Dumin 1986, Gaag-Sneijders-Flap 2008):

- legmagasabb presztízsű elért foglalkozás,

- erőforrás heterogenitás: az elért foglalkozási presztízsek terjedelme,

- teljes elért presztízs: az elért foglalkozási presztízsek összege,

- átlagos elért presztízs: az elért foglalkozások presztízspontszámának átlaga.

Az empirikus vizsgálatok azt mutatják, hogy az elemzéseket nem érdemes minden fenti változóra elvégezni. A nexusdiverzitás és a legmagasabb elért presztízs jó indikátorai a társadalmi erőforrásokhoz való hozzáférésnek (Gaag-Sneijders-Flap 2008).

A deduktív módszerek mellett a pozíciógenerátor lehetőséget nyújt arra is, hogy a változók összefüggési struktúrájára építve megkeressük azokat a foglalkozási miliő csoportokat, amelyek a segítségnyújtás szempontjából egymáshoz „közel” helyezkednek el. Ez a társadalmi tőke aspektusából azért lehet hasznos, mivel a különböző foglalkozási miliők más-más lehetőséget nyújthatnak a különböző erőforrások megszerzésének szempontjából. A foglalkozási miliő csoportok megtalálásához több statisztikai módszer is elvezethet, akár klaszterelemzés, akár valamilyen látens csoport kereső eljárás.

A módszer kellően rugalmas ahhoz, hogy tetszőlegesen kiterjeszthető legyen. Ilyenre példa Erickson (2004) társadalmi nem alapú megközelítése vagy Angelusz Róbert és Tardos Róbert pártokra kiterjesztett „pártgenerátor" módszere (többek között lásd Angelusz-Tardos 2009, további finomítása kapcsán pedig TardosKmetty-Fábián 2013).

9 Például a SIOPS96 rangsor alapján a megjelölt 24 foglalkozásból a pincérnek a legalacsonyabb a besorolása (a segédmunkás alatt jelentősen). 
A pozíciógenerátort szintén több adatfelvételben használták már Magyarországon. A névgenerátor esetében a már említett 1987-88-as kulturális és interakciós vizsgálatban az Angelusz-Tardos szerzőpáros már implementálta magyar viszonyokra a módszert 1997-ben és 1998-ban (Angelusz-Tardos 1998), 2005-ben és 2008-ban pedig megismételték ezeket a kutatásokat (bár nem volt teljesen egyező a foglalkozási lista). A 2014es MTA TK PTI Osztálylétszám kutatásban ${ }^{10}$ a pozíciógenerátoros módszerre épült a kapcsolati erőforrások feltérképezése. Az 1997 óta elkészült négy kutatás együttes elemzése a magas és alacsony státuszú kapcsolati miliők eltávolodását jelzik (Albert-Dávid-Kmetty-Tardos 2015).

\section{ERŐFORRÁS-GENERÁTOR}

Az erőforrás-generátort végső soron tekinthetjük a holland (európai) szociológia válaszának a pozíciógenerátorra, illetve arra a kérdésre, hogyan lehet legjobban mérni az egyének mikro-szintű társadalmi tőkéjét. A módszerhez elsősorban köthető szerzői kör Van der Gaag és Snijders (2004, 2005) abból indul ki, hogy bár a kapcsolathálózatok szerkezetét és méretét sokat vizsgálják, a kutatások azzal nem foglalkoznak, hogy e kapcsolathálózatokon keresztül milyen erőforrásokat lehet elérni, és végső soron mozgósítani. Ha mégis vannak ilyen kutatások, azok általában specifikus területeket érintenek, és az általános társadalmi tőkéről keveset tudnak mondani (Gaag-Snijders 2005). Az említett szerzők abban egyetértenek Linnel (1999, 2001), hogy a társadalmi erőforráshoz való hozzáférésekre kell koncentrálni elsősorban, nem a használatára, utóbbi inkább csak retrospektív helyzetekben használható fogalom anélkül, hogy túl sok nehezen tartható előfeltevést kellene tennünk (Gaag-Snijders 2005).

A módszer elméletileg abból indul ki, hogy az általános társadalmi tőke méréséhez meg kell határozni az életnek azokat a területeit, amelyek a célelérés szempontjából fontosak. Snijdersék szerint Lin pozíciógenerátoros módszere bár sok előnnyel rendelkezik (gyors, jól adaptálható különböző társadalmakra, egyszerű és jól használható mutatók képezhetők belőle), nem ad elég sokrétű képet az elérhető erőforrásokról, és a társadalmi tőkét is nagyon szúk értelmezési keretbe helyezi (Gaag-Snijders 2005).

Az erőforrás-generátor a szerzők célja szerint megpróbálja a névgenerátor és a pozíciógenerátor gyengéit meghaladni és előnyeiket összehangolni egy olyan módszerben, amelyben előre meghatározott erőforrásokhoz való hozzáférést vizsgálnak. A módszer felépítése hasonló a pozíciógenerátorhoz, azonban nem foglalkozásokat sorolnak fel a kérdezettnek, hanem azt vizsgálják, hogy tud-e bizonyos helyzetekben segítséget kérni, vagy van-e valamilyen tulajdonsággal rendelkező személy a kapcsolathálójában (van-e olyan ismerőse, aki vigyáz a gyerekére, segíthet munkát találni, van nyaralója, olvas irodalmat stb.). S ha igen, az illető vajon családtag, barát vagy ismerős. Mivel a szerzők elsősorban a társadalmi tőke szempontjából közelítik meg a kérdést, ezért az erőforrás-generátor esetében is az instrumentális cselekvés (célelérés) kerül a fókuszba, nem pedig az affektív cselekvés, bár utóbbira is vannak indikátorok. Ez a kettőség elméletileg vitatható is a koncepciójukban, de ez összefügg a társadalmi tőke elméletek megkérdőjelezhető értelmezésével is (Kmetty 2012). Míg Lin koncepciójában, még ha szúken is, de egyértelműen van levezetve a társadalmi tőke, az erőforrás-generátor problematikusnak tűnik ilyen szempontból. Annak a meghatározása és eldöntése, hogy egy adott cél elérésében melyek 
a fontos területek, elméleti szempontból is rengeteg kérdést vet fel, ráadásul a különböző társadalmakban ez nagyon különböző lehet.

A módszerből képezhető indikátorok nagy hasonlóságot mutatnak a pozíciógenerátorral. Egyfelől itt is definiálható nexusdiverzitás-mutató, ami azt méri, hány különböző erőforráshoz fér hozzá a kérdezett. A kapcsolathálózat volumene mellett a diverzitása legalább annyira fontos. Induktív logikából kiindulva klaszterelemezéssel, látens osztályokat kereső módszerekkel, vagy más hasonló logikára épülő statisztikai eljárással az erőforrások különböző csoportjai alakíthatók ki. Míg a pozíciógenerátor esetében ezek a csoportok elsősorban vertikális mintázatok, az erőforrás-generátor esetében inkább horizontálisak, és a különböző célelérési dimenziókhoz kapcsolódnak.

Snijdersék hivatkozott tanulmánya (Gaag-Snijders 2005) az általuk használt 37 itemes erőforrás-generátort használva négy csoportját különböztette meg a társadalmi tőke hozzáférésnek:

- presztízshez és oktatáshoz köthető társadalmi tőke (például az ismerősnek van nyaralója, ismeri az irodalmat, diplomás stb.),

- politikai és üzleti társadalmi tőke (például az ismerős aktív valamely pártban, kiismeri magát pénzügyi kérdésekben stb.),

- személyes képességekhez köthető társadalmi tőke (például az ismerős szaklapokat olvas, van autója, ért a számítógéphez stb.),

- segítségnyújtáshoz köthető társadalmi tőke (például az ismerős tud tanácsot adni munkahelyi konfliktusban, segít költözésben stb.).

Ahogy a fenti csoportosításból is látszik, a szerzők nagyon széles társadalmi tőke definíciós keretből indulnak ki, és a csoportokat alkotó itemek elméleti szempontból nem minden esetben rendeződnek tiszta csoportokba. Ennek kitűnő példája a segítéshez köthető társadalmi tőke. Ebbe a csoportba tartozik például a segítség személyes konfliktusok megoldásában és a munkahelyi ajánlás adása is. Nehezen látható azonban be, hogy egy affektív segítési háló elméletileg hogyan kerülhet azonos csoportba egy kifejezetten instrumentális kérdéssel, ami a munkához jutásra vonatkozik. Az itt kifejtett fenntartások ellenére fontos leszögezni, hogy a módszer a mikroszintű társadalmi tőke mérésének ígéretes lehetősége, de ehhez további elméleti kérdések várnak megválaszolásra.

A módszert eddig Magyarországon nagymintás országos kutatásban még nem alkalmazták, ezért itthoni eredmények és implementációk nincsenek.

\section{MÉRETGENERÁtOR}

Az eddig bemutatott módszerek a kapcsolathálózatokhoz elsősorban társadalmi erőforrás és társadalmi tőke szempontjából közelítettek. Legalább ennyire érdekes kérdés a hálózatkutatások helye a társadalmi struktúra kutatásokon belül. A társadalmi hálózatokban megfigyelhető homofília és a társadalmi struktúrában jelenlévő szegregáció bizonyos szempontból ugyanazon folyamatok mikro- és makroszintú megfelelői. A korábban bemutatott névgenerátor-technika (McAllister-Fischer 1978) elsősorban a közeli kapcsolatrendszer 
feltérképezésére alkalmas, és ezáltal a szúkebb mikrokörnyezeti hatásmechanizmusok feltárását teszi lehetővé, affektív hangsúllyal. A pozíciógenerátor (Lin-Dumin 1986), illetve az erőforrás-generátor módszerek (Van Der Gaag 2005), bár tágabb kontextusban vizsgálják az egyének kapcsolati hálóját, elsősorban a személyek instrumentális cselevési zónáit jelölik ki, és csak korlátozottan alkalmasak a társadalmi törésvonalak meghatározására. ${ }^{11}$ Az erőforrás-generátorhoz részben hasonló, úgynevezett méretgenerátoros módszer (összegző-módszer) alapjait McCarty és szerzőtársai (2001) fektették le még a 2000-es évek elején. A méretgenerátoros módszer tartalmilag a pozíciógenerátor és az erőforrás-generátor között helyezkedik el, azzal a lényeges különbséggel, hogy elsősorban társadalmi csoportokhoz köthető nexusokat vizsgál, és ezáltal a társadalmi választóvonalak, szegregációs határok kijelölésére különösen alkalmas. A méretgenerátoros módszer további előnye, hogy nem csak a kapcsolat meglétét vizsgálja, hanem azt is igyekszik számszerűsíteni, hogy adott társadalmi csoportból hány embert ismerünk. A hálózat vertikális nagyságának becslése egyes nevek kapcsolathálózati ismertségén alapszik. A nevek kapcsolathálózati és populációbeli megoszlásának segítségével megbecsülhető, hogy adott személy tágan vett ismeretségi körébe hány ember tartozik. A méretgenerátoros kérdőív modulban a nevek mellett konkrét társadalmi csoportokba tartozó ismerősök (például melegek, börtönviseltek, civil szervezet tagjai stb.) számára is rákérdeznek. E kapcsolatok számának ismerete lehetőséget teremt annak a megbecslésére, hogy a megkérdezett társadalmi csoportok mennyiben számítanak blokk-képzőnek. Másképpen: hogy az adott csoport mentén felfedezhetünk-e valamilyen kapcsolati elválasztó vonalat. A kapcsolati cezúra szegregációs jellege értelemszerúen a hátrányos helyzetű társadalmi csoportok (romák, melegek vagy börtönviseltek) esetén fordulhat elő, míg más esetekben (például a civil szervezeti tagságnál) inkább miliőhatárokról beszélhetünk.

Ezzel a módszerrel tehát nem az az elsődleges cél, hogy az egyének társadalmi struktúrában elfoglalt helyzetéről és lehetőségeiről mondjunk valamit, hanem az, hogy a társadalmi struktúráról összességben megállapításokat tehessünk, méghozzá az egyes csoportok kapcsolathálózati zártságán keresztül. A kapcsolathálózat nagyságának megbecslése ebben a módszerben, ahogy említettük, nevek alapján történik. Ebből következően nehezen lehet a kapcsolathálózat nagyságát erőforrásként, még kevésbé társadalmi tőkeként interpretálni, azt azonban axiómaként elfogadhatjuk, hogy a nagyobb kapcsolati háló a társadalmi integráció egyfajta fokmérője. A hátrányos helyzetű csoportokhoz való hozzáférés esetében pedig a negatív társadalmi tőke aspektusát is érinti a módszer.

\section{A méretgenerátorra épülő statisztikai modellek társadalomtudományi felhasználása}

A kapcsolathálózati blokkosodás vizsgálatára a következő módszer ad lehetőséget. Amennyiben abból a feltevésből indulunk ki, hogy a kapcsolathálózat kialakulását teljes mértékben a véletlen generálja, akkor feltételezhetjük, hogy ez a folyamat Poisson-eloszlást követ. ${ }^{12}$ Amennyiben a méretgenerátor esetében élünk ezen előfeltevéssel, akkor az egyes társadalmi csoportok kapcsán azt várjuk, hogy annak az eloszlása, hogy a minta tagjai hány embert ismernek adott társadalmi csoportból, szintén Poisson-eloszlást fog követni (ZhengSalganik-Gelman 2006; DiPrete et al. 2011). A társadalom azonban ennél bonyolultabb módon múködik: a

11 Bár e módszerek egyes kiterjesztései már lehetővé teszik a társadalmi törésvonalak bizonyos szempontok mentén való meghatározását (Angelusz-Tardos 2009).

12 A Poisson-eloszlás olyan aszimmetrikus diszkrét megoszlás, amit egy paraméterrel jellemezhetünk (szemben például a normál eloszlással, ahol két paraméterre is szükségünk van, az átlagra és a szórásra). 
kapcsolathálózat kialakulása és összetétele nem csupán a véletlen múve, strukturális és szociálpszichológiai mechanizmusok is befolyásolják a kapcsolathálózat kialakulását és összetételét. Nem feltételezhetjük tehát, hogy minden ember ugyanakkora valószínűséggel ismeri adott csoport tagját. ${ }^{13} \mathrm{~A}$ Poisson-eloszlástól vett ilyen jellegú eltérést a statisztikai szakirodalomban túlszórásnak (overdispersion) nevezik. Ha azt szeretnénk modellezni, hogy valaki hány embert ismer adott csoportból, akkor nem használhatunk egyszerú Poisson-modelleket, hanem a túlszórással korrigálni kell a becslésünket. A gyakorlatban ez azt jelenti, hogy Poisson- modellek helyett negatív binomiális modellek alkalmazására kerül sor (Moksony 2006), amely esetben úgynevezett a paraméterrel jelölik a túlszórás mértékét: minél magasabb az $\alpha$ paraméter, annál nagyobb a statisztikai értelemben vett túlszórás. ${ }^{14} \mathrm{E}$ modell alkalmazása két előnnyel is jár: egyfelől a túlszórással korrigált negatív binomiális modellek használata megbízhatóbb becslésekhez juttathat minket, hiszen a társadalmi realitás jobban megfelel a modellek előfeltételeinek. Másfelól, a modell illesztéséhez felhasznált a paraméter nem csak statisztikai értelemben fontos, hanem társadalomtudományi szempontból is tartalmi információval jár: az a paraméter alapján azt is megbecsülhetjük, hogy adott csoport esetében milyen erős kapcsolati cezúráról beszélhetünk. Azaz, ha azt szeretnénk összevetni, hogy mennyire mélyek a törésvonalak a különböző társadalmi csoportok esetében, akkor az a paraméter lehetővé teszi ezt számunkra (DiPrete et al. 2011, Kmetty-Koltai 2014). Fontos kiemelni, hogy a modellek segítségével a kapcsolati cezúrák detektálásán túl arra is lehetőségünk nyílik, hogy megállapítsuk, mely változók mentén erősödnek és melyek mentén gyengülnek ezek a társadalmi elválasztó vonalak. Ennek elérése érdekében a negatív binomiális modellekbe érdemes hierarchikusan beépíteni független változókat, így az egyes változók beillesztése után az a paraméter csökkenéséből következtethetünk arra is, hogy az adott változó mentén mennyire erős az elválasztó vonal. Másképpen: hogy az adott változó mennyire „felel” a társadalmi csoport szegregációjáért, tömbösödésért. ${ }^{15}$

\section{Nehezen mérhető csoportok nagyságának becslése}

A méretgenerátoros módszer alapján arra vonatkozóan is tehetünk becsléseket, hogy mekkora az ennek keretében lekérdezett - általában nehezen mérhető - csoportok nagysága a társadalomban. A társadalmi törésvonalak ugyanis sokszor olyan csoportokat érintenek, melyek körülhatárolhatósága, nagyságának definiálása meglehetősen problematikus (lásd például a melegek vagy hajléktalanok csoportját). A méretgenerátoros módszer alkalmazásával azonban annak figyelembevételével, hogy ismerjük a kérdezettek kapcsolathálózatának nagyságát és ezen belül az adott csoport tagjainak arányát, lehetőség nyílik az egész társadalomra vonatkozóan a nehezen mérhető csoportok nagyságának megbecslésére is. Fontos megjegyezni, hogy a méretgenerátoros módszerrel inkább alulbecsüljük a csoportok nagyságát (Kmetty-Koltai 2014). Ez elméleti szempontból is alátámasztható. Egyrészt, ha bizonyos csoportok esetében feltételezünk látenciát, akkor az nem csak a túlszórásra hathat (a csoporton kívüliek ki vannak zárva, ami növeli a túlszórást), hanem a megfigyelt kapcsolatszám vár-

13 Van, aki például viszonylag sok meleget ismer, valaki pedig egyet sem.

14 Abban az esetben ugyanis, amikor egy társadalomban mindenki nagyjából azonos valószínűséggel ismeri egy adott csoport tagját (tehát például mindenki azonos valószínűséggel ismer hajléktalant), az a paraméter értéke nulla, azaz a negatív binomiális modell igazából Poisson-modellé válik.

15 Ebben az esetben előfeltevésünk az, hogy azért van túlszórás a modellekben, mert nem szerepeltetünk olyan magyarázó változókat, amelyek kontrollálása után csökkenne, vagy eltűnne a túlszórás. 
ható értékét is csökkenti. A módszerre támaszkodó számítások a társadalmi csoportok számának alsó becslésének tekinthetők, vagy fogalmazhatunk úgy is, hogy a csoport jól identifikálható szereplőinek számát tudjuk így megbecsülni. Alacsony látencia és magas láthatóság esetében (például hajléktalanság) becsléseink viszont várhatóan jóval pontosabbak. Az alulbecslést az is erősítheti, hogy ha valamely társadalmi csoporttal szemben olyan típusú kapcsolati cezúra alakul ki, hogy nem csak a csoporton kívüliek utasítják el a csoportot, hanem ezen felül a csoporton belüliek inkább a kapcsolat nélküliséget választják a saját csoportjukkal való kapcsolat helyett. Ilyen mechanizmus múködhet például a börtönviseltek esetében.

\section{A méretgenerátoros módszer összefoglalása}

Összességében tehát a méretgenerátoros módszerrel többféle elemzési cél is elérhető. Egyrészt mérhető a kérdezettek kapcsolathálózatának nagysága és vizsgálható, hogy egy társadalomban mitôl függ a kapcsolatháló mérete. Másrészt a kérdezettek kapcsolathálózatának összetételén keresztül kapcsolati cezúrák és azok nagysága is feltérképezhető, továbbá detektálhatók az egyének azon jellemzői, amelyek mentén ezen elválasztó vonalak erősebbek vagy gyengébbek. Végül pedig lehetőség nyílik a módszer keretein belül kérdezett - sokszor nehezen mérhető - társadalmi csoportok nagyságának becslésére is.

A módszer flexibilitása egyszerre előnyös és hátrányos. Előny, mert könnyen átalakitható bármilyen speciális kutatási problémára (politikai alkalmazás kapcsán lásd például Kmetty 2014, 2015). Hátrány, mert nincs egységes kutatási gyakorlat, ami eligazítana, hogy melyek azok a releváns kapcsolathálózati cezúrák, amelyeket vizsgálni érdemes. Utóbbi probléma a kultúrák és országok közötti összehasonlítás lehetőségeit is nagyban megnehezíti.

Magyarországon eddig három alkalmazása volt a módszernek: 2012-ben az ELTE TÁTK Módszertani központ által lebonyolított Budapest kutatás, 2014-ben pedig egy Tárki omnibusz felvételben szerepelt egy politikai változata a módszernek, illetve az MTA-ELTE Peripato kutatócsoport „Válság és Innováció” adatfelvételében (ezekről bővebben lásd Kmetty 2014, 2015, Kmetty-Koltai 2014).

\section{ÖSSZEFOGLALÁS}

Tanulmányunkban a kapcsolathálózatok mérésének komplex módszerei közül a négy leginkább elterjedt technikát mutattuk be. Tanulmányunk korlátaival már az írás elején foglalkoztunk, ezt annyival mindenképp ki kell egészítenünk, hogy az itt bemutatott módszerek is több változatban megtalálhatók a társadalomtudományi munkákban. Mind a négy módszer esetében igyekeztünk a „klasszikus” tanulmányokra támaszkodni. A következő táblázatban összefoglaltuk a módszerek legfontosabb jellemzőit. 
1. táblázat. A különböző módszerek előnyei és hátrányai

\begin{tabular}{|c|c|c|c|c|c|}
\hline & Mit mér? & Kötéserősség & Mire jó? & Előnyök & Hátrányok \\
\hline Név-generátor & $\begin{array}{l}\text { főleg affektív } \\
\text { (részben instru- } \\
\text { mentális) segíté- } \\
\text { si hálót }\end{array}$ & $\begin{array}{l}\text { inkább erősebb, } \\
\text { mag-kapcsolatok }\end{array}$ & $\begin{array}{l}\text { kapcsolati } \\
\text { erőforrások, } \\
\text { mikro-integráció, } \\
\text { jól-lét }\end{array}$ & $\begin{array}{l}\text { mikro-szintű } \\
\text { homofília vizs- } \\
\text { gálata, nagyon } \\
\text { tág elemzési } \\
\text { lehetőségek }\end{array}$ & $\begin{array}{l}\text { hosszú kérdőív } \\
\text { blokk, nincs álta- } \\
\text { lánosan használt } \\
\text { kérdéssor }\end{array}$ \\
\hline $\begin{array}{l}\text { Pozíció- } \\
\text { generátor }\end{array}$ & $\begin{array}{l}\text { foglalkozási } \\
\text { típusokhoz való } \\
\text { hozzáférést }\end{array}$ & $\begin{array}{l}\text { erős és gyenge } \\
\text { kötések egyaránt }\end{array}$ & $\begin{array}{l}\text { kapcsolatháló- } \\
\text { zati erőforrások, } \\
\text { társadalmi tőke } \\
\text { (szűkebb megkö- } \\
\text { zelítés) }\end{array}$ & $\begin{array}{l}\text { jól definiált } \\
\text { probléma-meg- } \\
\text { közelítés, rövid } \\
\text { kérdőív }\end{array}$ & $\begin{array}{l}\text { foglalkozások } \\
\text { kultúránként és } \\
\text { országonként } \\
\text { eltérő presztízse, } \\
\text { társadalmi tőke } \\
\text { szűk értelmezése }\end{array}$ \\
\hline $\begin{array}{l}\text { Erőforrás- } \\
\text { generátor }\end{array}$ & $\begin{array}{l}\text { erőforrásokhoz } \\
\text { való hozzáférést }\end{array}$ & $\begin{array}{l}\text { erős és gyenge } \\
\text { kötések egyaránt }\end{array}$ & $\begin{array}{l}\text { kapcsolatháló- } \\
\text { zati erőforrások, } \\
\text { társadalmi tőke } \\
\text { (tágabb megkö- } \\
\text { zelítés) }\end{array}$ & $\begin{array}{l}\text { széles indikátor- } \\
\text { készlet különféle } \\
\text { célelérésekhez, } \\
\text { viszonylag rövid } \\
\text { kérdőív }\end{array}$ & $\begin{array}{l}\text { túl széles } \\
\text { társadalmi tőke } \\
\text { koncepció, nincs } \\
\text { egységes fogalmi } \\
\text { keret a fontos } \\
\text { társadalmi terü- } \\
\text { letekről }\end{array}$ \\
\hline Méret-generátor & $\begin{array}{l}\text { társadalmi cso- } \\
\text { portokhoz való } \\
\text { hozzáférést }\end{array}$ & $\begin{array}{l}\text { erős és gyenge } \\
\text { kötések egyaránt }\end{array}$ & $\begin{array}{l}\text { teljes kapcsolat- } \\
\text { hálózat volume- } \\
\text { ne, kapcsolat- } \\
\text { hálózati törés- } \\
\text { vonalak, tágabb } \\
\text { értelemben } \\
\text { makro-társadal- } \\
\text { mi szegregációs } \\
\text { határok }\end{array}$ & $\begin{array}{l}\text { viszonylag } \\
\text { rövid kérdőív, a } \\
\text { makrotársadalmi } \\
\text { struktúra újszerű } \\
\text { vizsgálata, } \\
\text { mikro-makro } \\
\text { mechanizmusok } \\
\text { összekapcsolása }\end{array}$ & $\begin{array}{l}\text { releváns csopor- } \\
\text { tok kiválasztásá- } \\
\text { nak problémája, } \\
\text { nehézkesen } \\
\text { lehet csak a } \\
\text { kapcsolathálózati } \\
\text { erőforrásokról } \\
\text { relevánst mon- } \\
\text { dani a módszerre } \\
\text { támaszkodva }\end{array}$ \\
\hline
\end{tabular}

A fenti táblázat is mutatja, hogy a különböző módszerek eltérő kutatási kérdések megválaszolásához járulhatnak hozzá. Bár mind a négy kapcsolathálózatot vizsgál, ezt igen eltérő szempontból teszik. A megfelelő módszer kiválasztása tehát elsősorban nem módszertani kérdés, hanem sokkal inkább tartalmi, elméleti probléma. A méretgenerátoros kutatási módszer a 2015-ben lekérdezésre kerülő Integráció és dezintegráció a magyar társadalomban című OTKA kutatási program adatfelvételébe is bekerült a névgenerátorral és a pozíciógenerátorral közösen. Ez egy olyan elemzési keretet nyit ki, ami nemzetközi szinten is egyedüláló megértését eredményezheti a kapcsolathálózati momentumok egymásba fonódási mechanizmusainak, valamint ezek integrációban betöltött szerepének megértésében. Reményeink szerint tanulmányunk ezen munkában jó kiinduló alapot fog jelenti. 


\section{HIVATKOZÁSOK}

Albert F. - Dávid B. (2007) Embert barátjáról - a barátság szociológiája. Budapest: Századvég.

Albert F. - Dávid B. - Kmetty Z. - Tardos R. (2015) Mapping social milieus and cohesion patterns. Exploiting the potential of occupational position generator. XXXV SUNBELT Conference of the International Network for Social Network Analysis, 23-28 June 2015, Brighton UK.

Angelusz R. (2010) Tőke vagy erőforrás. Adalékok a társadalmi tőke elméletéhez. Szociológiai Szemle, 20(3), 147-166.

Angelusz R. - Tardos R. (1988) A magyarországi kapcsolathálózatok néhány sajátossága. Szociológiai Szemle (2).

Angelusz R. - Tardos R. (1998) A kapcsolathálózati erőforrások átrendeződésének tendenciái a kilencvenes években. In Kolosi, T. Tóth, I. Gy. - Vukovich, Gy. (szerk.) Társadalmi riport 1998. Budapest: TÁRKI, 237-256.

Angelusz R. - Tardos R. (2006) Hálózatok a magyar társadalomban. In Kovách I. (szerk.) Társadalmi metszetek. Érdekek és hatalmi viszonyok, individualizáció és egyenlőtlenség a mai Magyarországon. Budapest: Napvilág kiadó, 227-252.

Angelusz R. - Tardos R. (2008) Assessing Social Capital and Attainment Dynamics - Position Generator Applications in Hungary, 1987 2003. In Lin, N. - Erickson, B. H. (szerk.) Social Capital: An International Research Program. Oxford: Oxford University Press, 394-420. http://dx.doi.org/10.1093/acprof:oso/9780199234387.003.0172.

Angelusz R. - Tardos R. (2009) A kapcsolathálózati szemlélet a társadalom- és politikatudományban. Politikatudományi Szemle, 18(2), 29-57.

Barabási A. L. (2002) Behálózva - A hálózatok új tudománya. Budapest: Helikon kiadó.

Burt, R. (1992) Structural holes: the Social structure of Competition. Cambridge, Massachusetts: Harvard University Press.

DiPrete, T. A. - Gelman, A. - McCormick, T. - Teitler, J. - Zheng, T. (2011) Segregation in Social Networks based on Acquaintanceship and Trust. American Journal of Sociology, 116(4), 1234-1283. http://dx.doi.org/10.1086/659100.

Erdős P. - Rényi A. (1960) On the evolution of random graphs. MTA Matematikai Kutatóintézeti Közlemények 5, 17-61.

Erickson, B. H. (2004): The Distribution of Gendered Social Capital in Canada. In Flap, H. - Volker, B. (szerk.) Creation and Returns of Social Capital: A New Research Program. London and New York: Routledge, 27-50.

Flap, H. (1991) Social capital in the production of inequality. A review. Comparative Sociology of Family, Health, and Education, 20: 6179-6202.

Fu, Y. (2008) Position Generator and Actual Networks in Everyday life: An evaulation with Contact Diary. In Lin, N. - Erikson, B. H. (szerk.) Social Capital. An International Research Program. Oxford: Oxford University Press, 49-64. http://dx.doi.org/10.1093/acprof:oso/9780199234387.003.0022

Ganzeboom, H. B. G. - Treiman, D. J. (1996): Internationally Comparable Measures of Occupational Status for the 1988 International Standard Classification of Occupations. Social Science Research, 25(3), 201-239. http://dx.doi.org/10.1006/ssre.1996.0010.

Granovetter, M. (1973) The Strength of Weak Ties. American Journal of Sociology, 78(6), 1360-1380. http://dx.doi.org/10.1016/b978-0-12-442450-0.50025-0.

Huckfeldt, R. R. - Mendez, J. M. (2008) Moths, Flames, and Political Engagment. Managing Disagreement within Communication Netwokrs. Journal of Politics, 70(1), 83-96. http://dx.doi.org/10.1017/s0022381607080073

Huszti É. (2013) A negyedik út. Az egocentrikus kapcsolati háló vizsgálata a „network napló“ módszer alkalmazásával. Doktori disszertáció, ELTE-TÁTK szociológia doktori iskola.

Huszti É. (2015) Megismer-hetem: a személyes kapcsolathálózat feltárásának új formája: kapcsolati napló. Debrecen: Debreceni Egyetemi Kiadó.

Kisfalusi D. (2013) Kapcsolati és hálózati tőke: Vázlat a társadalmi tőke kettős természetéről. Szociológia Szemle, 23:(3) 84-101.

Kmetty Z. (2012) Egy fogalom margójára. Civil Szemle, 9(1), 15-22.

Kmetty Z. (2014) Diskurzusok, nexusok és politikai részvétel: A politikai hálózatok és a politikai diskurzus szerepe a részvételben és a tömbösödésben. Doktori disszertáció, Budapest ELTE-TÁTK Szociológia Doktori Iskola. http://dx.doi.org/10.13140/2.1.2496.5128.

Kmetty Z. (2015) Ideológia és kapcsolathálózati törésvonalak a társadalmi-politikai térben a 2014-es országgyúlési választások előtt. Studies in Political Science 2015(1) 8-34.

Kmetty Z. - Koltai J. (2012) A kommunikáció intenzitásának és heterogenitásának hatása a részvételre. In Kmetty Z. - Koltai J. (szerk.) Változó képletek, változatos perspektivák. Tanulmánykötet Tardos Róbert 65. születésnapjára. Budapest: Háttér Kiadó, 158-209.

Kmetty Z. - Koltai J. (2014) Structural rifts - a new, network based method for the exploration of social cleavages. Paper for the 25th Jour Fixe, Akadémiai Szimpózium 2014. 09. 25. MTA Társadalomtudományi Kutatóközpont, Szociológiai Intézet. 
Kogovsek, T. - Mrzel, M. - Hlebec, V. (2010) Please name the two People you would ask for help: The Effect of limitation of the Number of Alters on Network Composition. Metodolski zvezki, Vol.7 No. 2, 95-107.

Koltai J. - Ságvári B. (2014) The Growth of an Online Social Network: Diffusion and Methodological Challenges. Presentation for CEU Center for Network Science - TK "Lendület" Recens research group, Central European University, Budapest.

Kowald M. - Axhausen K. W. (2011) Strong and weak relationships: tie strengths in egocentric leisure networks. Conference paper for the 106th American Sociological Association Annual Meeting, Chicago, August 2011.

Kulcsár R. (1985) Az első magyar országos presztízsvizsgálat eredményei. Statisztikai Szemle, 62(11), 1115-1126.

Lazarsfeld, P. - Merton, R. (1954) Friendship as Social Process: A Substantive and Methodological Analysis. In Kendall, P. L. (szerk.) The Varied Sociology of Paul F. Lazarsfeld. New York: Columbia University Press, 298-348.

Lin, N. - Dumin, M. (1986) Access to Occupations through Social Ties. Social Networks, 8(4), 365-85. http://dx.doi.org/10.1016/0378-8733(86)90003-1.

Lin, N. (1999) Building a Network Theory of Social Capital. Connections, 22(1), 28-51.

Lin, N. (2001) Social Capital: A Theory of Structure and Action. London: Cambridge University Press. http://dx.doi.org/10.1017/cbo9780511815447.

Lin, N. (2008) A network theory of social capital. In Castiglione, D. - van Deth, J. W. -Wolleb, G. (szerk.) The handbook of social capital. New York: Oxford University Press, 50-69.

Lin, N. - Erickson, B. H. (2008) Theory, Measurement, and the Research Enterprise on Social Capital. In Lin, N. - Erikson, B. H. (szerk.) Social Capital. An International Research Program. Oxford: Oxford University Press, 1-24.

Marsden, P. V. (1987) Core Discussion Network of Americans. American Sociological Review, 52(1), 122-131. http://dx.doi.org/10.2307/2095397.

Marsden, P. V. (1990) Network Data and Measurement. Annual Review of Sociology, 16, 435-463. http://dx.doi.org/10.1146/annurev.soc.16.1.435

Marsden, P. V. (2003) Interviewer effects in measuring network size using a single name generator. Social Networks, 25(1), 1-16. http://dx.doi.org/10.1016/s0378-8733(02)00009-6.

Marin, A. - Hampton, K. N. (2007) Simplifying the personal network name generator alternatives to traditional multiple and single name generators. Field methods, 19(2), 163-193. http://dx.doi.org/10.1177/1525822x06298588

McAllister, L. - Fischer, C. S. (1978) A Procedure for Surveying Personal Networks. Sociological Methods and Research, 7(2), 131-148. http://dx.doi.org/10.1177/004912417800700202.

McCarty, K. - Killworth, P. D. - Bernard, H. R. - Johnsen, E. C. - Shelley, G. A. (2001) Comparing Two Methods for Estimating Network Size. Human Organization, 60(1), 28-39. http://dx.doi.org/10.17730/humo.60.1.efx5t9gjtgmga73y.

McPherson, M. - Smith-Loving, L. - Cook, J. M. (2001) Birds of a Feather: Homophily in Social Network. Annual Review of Sociology, 27, 415-234. http://dx.doi.org/10.1146/annurev.soc.27.1.415.

Mérei F. (1988) Közösségek rejtett hálózata. Budapest: Tömegkommunikációs Kutatóközpont.

Moksony F. (2006) A Poisson-regresszió alkalmazása a szociológiai és demográfiai kutatásban. Demográfia, 49(4), 366-382.

Moreno, J. (1934) Who shall survive? Boston: Beacon. http://dx.doi.org/10.1037/10648-000

Mutz, D. C. (2002a) The Consequences of Cross-Cutting Networks for Political Participation. American Journal of Political Science, 46(4), 838-855. http://dx.doi.org/10.2307/3088437.

Mutz, D. C. (2002b) Cross-cutting social networks: Testing Democratic Theory in Practice. Americal Political Science Review, 96(1): 111-126. http://dx.doi.org/10.1017/s0003055402004264.

Sik E. (2006) Tőke-e a kapcsolati tőke, s ha igen, mennyiben nem? Szociológia Szemle, 16(2), 72-95.

Sik E. (2012) A kapcsolati tőke szociológiája. Budapest: Eötvös Loránd Tudományegyetem, Eötvös Kiadó.

Snijders T. - Spreen M. - Zwaagstra R. (1995) The use of multilevel modeling for analysing personal networks: Networks of cocaine users in an urban area. Journal of quantitative anthropology, 5(2), 85-105.

Tardos R. - Kmetty Z. - Fábián Z. (2013) Political Position Generator: New ways in studying Electoral Segmentation. XXXIII Sunbelt Conference, 2013.05.23. Hamburg, INSNA.

Treiman, D. J. (1977) Occupational Prestige in Comparative Perspective. New York: Academic Press. http://dx.doi.org/10.1016/b978-0-12-698750-8.50019-x

Van der Gaag, M. P. J. - Snijders, T. A. B. (2004) Proposals for the measurement of individual social capital. In Flap, H. - Volker, B. (Eds.) Creation and Returns of Social Capital. Routledge, London, 199-218. 
Van der Gaag, M. P. J. - Snijders, T. A. B. (2005) The Resource Generator: social capital quantification with concrete items. Social networks, 27(1), 1-29. http://dx.doi.org/10.1016/j.socnet.2004.10.001.

Van der Gaag, M. P. J. (2005) Measurement of individual social capital. Amsterdam: F\&N Boekservices.

Van der Gaag, M. P. J. - Snijders, T. A. B. - Flap, H. D. (2008) Position Generator measures and their relationship to other social capital measures. In: Lin, N. - Erickson, B. H. (szerk.) Social capital: An International Research Program. Oxford: Oxford University Press, 185-205. http://dx.doi.org/10.1093/acprof:oso/9780199234387.003.0011.

Vedres B. (2012) Strukturális gyúrődések: a hálózatok innovatív feszültségei. In Kmetty Z. - Koltai J. (szerk.) Változó képletek, változatos perspektivák. Tanulmánykötet Tardos Róbert 65. születésnapjára. Budapest: Háttér Kiadó, 92-110.

Wasserman, S. - Faust, K. (1994) Social network analysis in the social and behavioral sciences. Social network analysis: Methods and applications, 1-27. http://dx.doi.org/10.1017/cbo9780511815478.002.

Zheng, T. - Salganik, M. J. - Gelman, A. (2006) How many people do you know in prison? Using overdispersion in count data to estimate social structure in networks. Journal of the American Statistical Association, 101(474), 409-423. http://dx.doi.org/10.1198/016214505000001168. 